\title{
窒化銅薄膜の電気特性の評価および 水素注入の影響十
}

\author{
石川努增田正孝林安徳 \\ 九州大学大学院工学研究科
}

J. Japan Inst. Metals, Vol. 63, No. 5 (1999), pp. 621-624

Papers from JIM Fall Meeting (1998)

\section{Characterization on the Electrical Properties of Copper Nitride Thin Films and the Effects of Hydrogen Implantation}

\author{
Tsutomu Ishikawa ${ }^{\dagger \dagger}$, Masataka Masuda and Yasunori Hayashi \\ Graduate School of Engineering, Kyushu University, Fukuoka 812-8581
}

\begin{abstract}
Recently, compound semiconductor thin films have been studied very actively for applications to electrical and optical devices that could be the base of the information industry. But the study of metal nitride thin films has not proceeded faster than that of metal oxide thin films. And there are some nitrides that have not been studied on their fundamental properties. In this paper, copper nitride $(\mathrm{Cu}-\mathrm{N})$ thin films were prepared by reactive $\mathrm{RF}$ sputtering and the relation between electrical properties and sputtering conditions were investigated. As a result, it was clear that the properties of $\mathrm{Cu}-\mathrm{N}$ thin films were connected with sputtering conditions, especially the content of nitrogen gas and deposition rate of $\mathrm{Cu}-\mathrm{N}$ thin films. Various $\mathrm{Cu}-\mathrm{N}$ thin films that were prepared under different conditions had a band gap in the range of $0.5-1.5 \mathrm{eV}$ and their resistivity values were widely changed. Lower values of band gap energy and resistivity than reported values indicated that these $\mathrm{Cu}-\mathrm{N}$ films are non-stoichiometry and they are supposed to have many defects. Hydrogen implantation treatment of the samples was done in order to improve their properies such as band gap energy, resistivity and carrier density. In result, electrical resistivity drastically decreased from $10^{2}$ to $10^{-4} \Omega \mathrm{m}$ with increasing carrier density. And the structural peculiarity was not influenced by hydrogen implantation. This result shows that implanted hydrogen ions could produce electrons correlated to electrical conduction.
\end{abstract}

(Received January 22, 1999; In Final Form March 15)

\begin{abstract}
Keywords: copper nitride, reactive radio-frequency sputtering, band gap energy, resistivity, Hall measurement, hydrogen implantation, stoichiometry, non-stoichiometry
\end{abstract}

\section{I.は じめに}

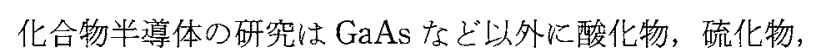
炭化物そして窒化物を用いて行わ秃てさたが，これらの化合 物をドライな環境で作製する際には様々な作製方法がとられ ている。その中でも反応性スパッタリング法は比較的容易に 化合物を作製することが可能で，をた化合物の組成を広範囲 で変化させることがでさる．最近，絰化物薄膜の研究が非常 に盛ん行わ行ているが，そのなかでも而－V族窒化物はそ の光学特性や電気特性が非常に優れているため，その作製方 法, 特性評価の両面から研究が進えでいる(1)-(3)。乙かしな がら，それ以外の窒化物はその基本的な特性さえ无明らかに なっていないものが多い，そこで本稿机いては絰化物とし て窒化銅 $(\mathrm{Cu}-\mathrm{N})$ (4)(5)を作製し，その電気特性の評価を広く 行った。本研究で作製した窒化銅薄膜は化学量論組成に和い て $\mathrm{Cu}_{3} \mathrm{~N}$ といら化合物になることが知られている。この $\mathrm{Cu}_{3} \mathrm{~N}$ は逆三酸化レニウム $\left(\right.$ anti- $\left.\mathrm{ReO}_{3}\right)$ 構造という特異な結

†1998年 9 月28日日本金属学会秋期大会に拁いて発表

故九州大学大学院生 (Graduate Student, Kyushu University)
晶構造を有するために，興味深い特性を持つ可能性を秘めて いる。例光ば，Maruyama ら(4) は反応性 RFスパッタリン グ法で作製した窒化銅薄膜は作製条件の変化によって，良導 体から絶縁体に束でその電気抵抗率が変化することを報告し た，ところで，水素注入処理はSi 中のダングリングボンド を終端したり，不純物半導体に郝子るクセプターやドナー と相互作用することで材料の光学，電気特性を大さく变化さ せることが可能である(6). しかし化合物半導体への水素注入 はこれまであまり報告されていない，本研究では組成の異な る様ふな窒化銅薄膜に対して水素イオンを注入し，窒化銅薄 膜の特性がいか化変化するかを調査した。

\section{II. 実 験 方 法}

窒化銅薄膜の作製にはRFスパッタリング装置(日電アネ ルバ製 SP-210B EFP-00128）を用いた。応性がスである $\mathrm{N}_{2}$ と不活性ガスである $\mathrm{Ar}$ の流量は成膜中一定とし，成膜 中の窒素ガス割合は窒素分圧で調節した。成膜条件の詳細は Table 1 K示す。作製した咥化銅薄膜の構造解析はCo の特 性 X 線を用いてX 線回折測定 $(\mathrm{XRD}) を$ 
Table 1 Sputtering condition for $\mathrm{Cu}-\mathrm{N}$ films.

\begin{tabular}{lc}
\hline Base pressure & $1.33 \times 10^{-4} \mathrm{~Pa}$ \\
Total gas pressure & $66.7 \mathrm{~Pa}$ \\
Content of $\mathrm{N}_{2}$ & $0 \sim 100 \%$ \\
rf power & $100 \mathrm{~W}$ \\
Sputtering time & $1.8,2.7,3.6 \mathrm{ks}$ \\
Presputtering time & $2 \mathrm{~h}$ \\
Substrate & Soda-lime glass \\
Substrate temperature & Room temperature \\
\hline
\end{tabular}

表面形状測定機(ランクテーラーホブソン社製)で測定した. 電気抵抗率は室温に打いて四端子法の一種である van der Pauw 法(7)で測定し，ホール測定も同様の方法で $0.2 \mathrm{~T}$ の磁 場中で行った，窒化銅薄膜の透過率，反射率測定は分光光度 計(UV160A 分光光度計島津製作所製) 用いて，入射波長 域 200 1100 nm て測定した. 測定後, 透過率，反射率の值 から光の吸収係数とバンドギャップエネルギーを計算し た(7)、水素イオン注入はイオン銃(日電アネルバ社製)を用い て行った。イオン注入時間は $1 \mathrm{~h} と し ，$ 加速電压は $3 \mathrm{kV}$ と した。水素イオンを注入中の真空度は約 $2.7 \times 10^{-4} \mathrm{~Pa}$ であ

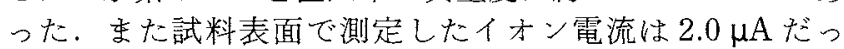
た。イオン電流密度は $2.0 \times 10^{-2} \mathrm{~A} / \mathrm{m}^{2}$ となった。

\section{III. 実験結果および考察}

\section{1. 窒化銅薄膜の諸特性と成膜条件の関係}

Fig. 1 亿窒化銅薄膜の成膜速度と窒素がス割合の関係を 示す。この図から，明らかに窒素がス割合が増加するにした がって成膜速度が遅くなっていることが分かる。これは，空 素ガス割合が上昇することによって相対的にターゲットに衝 突するArイオンの数が減少し，そのためスパッタされる $\mathrm{Cu}$ 原子の数も減少したと考穴られる。市た Fig. 1 で示す領 域はある成膜速度を境界線と乙て膜の配向性が異なることを 意味する。様々な窒化銅薄膜のXRD測定結果をFig. 2 に 示す. Fig. 2(a)は Fig. 1 の領域(1)火属する膜の典型的な


(c) 䕘域(3)の典型的な XRD プロファイルである。このよ 与に本研究で作製した窒化銅薄膜は成膜速度が遅い時には $\mathrm{Cu}_{3} \mathrm{~N}(100)$ 面や $\mathrm{Cu}_{3} \mathrm{~N}(200)$ 面からの回折ピークが強いが， 速くなるにつ机て $\mathrm{Cu}_{3} \mathrm{~N}(111)$ 面からの回折ピークが強くな る。一般にスパッタリングによる薄膜形成を考兵る際に，成 膜速度が十分遅く，委た基板が非晶質であるときは結晶の最 密面が基板面と平行になることが知られている(8).Fig. 1 と Fig. 2 から, 窒素がス割合が高い時には成膜速度が遅いため $\mathrm{Cu}_{3} \mathrm{~N}$ の最密面である(100)面からの回折ピークが強く現れ ているが，窒素がス割合が低い場合には長時間成膜すると， 最密面の堆積による膜成長をしないため $\mathrm{Cu}_{3} \mathrm{~N}(111)$ 面から の回折ピークが現れると思われる。これは窒素がス割合が低 い場合，つ变り成膜速度がある程度速い場合に出いても，や はり膜成長の初期段階に和いてはガラス基板の影響で $\mathrm{Cu}_{3} \mathrm{~N}$ の最密面(100)面が基板に平行となるよらに成長する。しか 乙時間の経過とともに膜厚が増大すると既に形成されている 最密面上での原子移動は成膜速度が速いために妨げられ，膜 表面の銅原子や窒素原子は最密面を形成しなくなり，その結 果, $\mathrm{Cu}_{3} \mathrm{~N}(100)$ ピークが小さくなり (111) ピークなどが現れ るのである。

Fig. 3 K成膜時間と窒素ガス割合を変化させて作製した

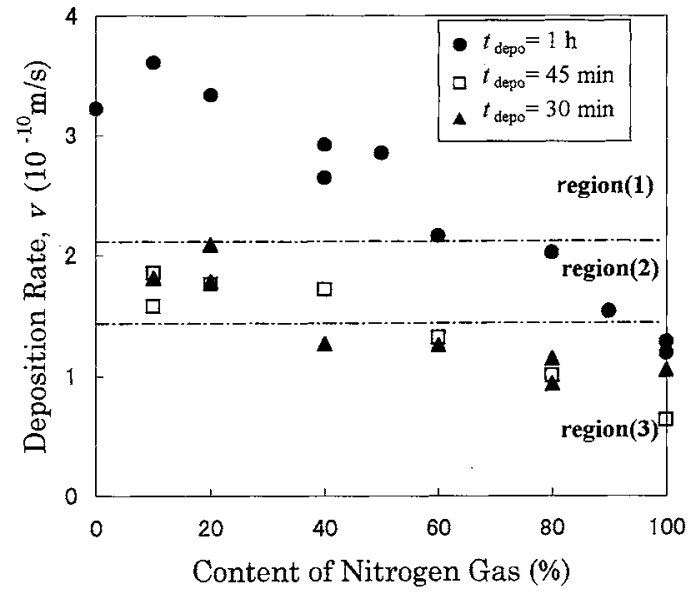

Fig. 1 Dependence of deposition rate on the content of nitrogen gas during the preparation of $\mathrm{Cu}-\mathrm{N}$ films. In this figure, $t_{\text {depo }}$ means the deposition time of $\mathrm{Cu}-\mathrm{N}$ films.



Fig. 2 X-ray diffraction profiles for $\mathrm{Cu}-\mathrm{N}$ films that belong to different regions in Fig. 1; (a) a typical X-ray profile that belongs to the region (1) in Fig. 1, (b) a typical profile that belongs to region (2) and (c) a typical profiles that belongs to region (3).

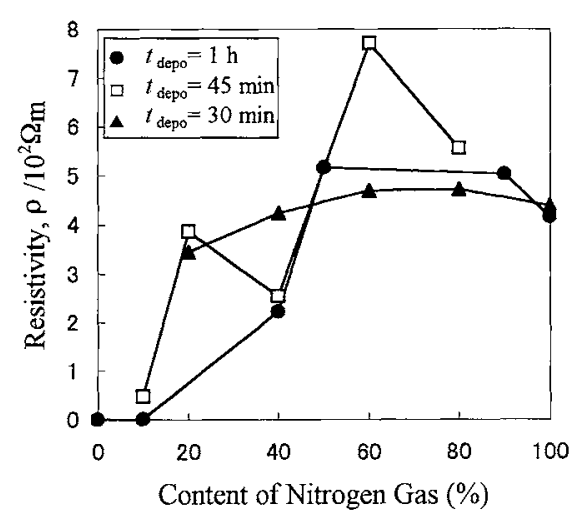

Fig. 3 Dependence of resistivity on the content of nitrogen gas. In this figure, $t_{\text {depo }}$ means the deposition time of $\mathrm{Cu}-\mathrm{N}$ films. 
窒化銅薄膜の電気抵抗率と窒素ガス割合の関係を示す。成膜 時間の違いによりその挙動は多少異なるが，全体的には窒素 ガス割合が増加する注ど電気抵抗率も増加しているのが明ら かである。しかしながら，窒素がス割合 $100 \%$ 場合，その 電気抵抗率はアルゴンガスを10\%でも導入した場合に比べ ると小さくなる。Fig. 4(a)，(b)にホール测定結果を示す. 本研究の条件で作製した窒化銅薄膜はすべてホール係数が負 であったため， $\mathrm{n}$ 型半導体であることが判明した。 また。こ れらの図から成膜時間によらず, キャリア密度は窒素がス割 合方増加する汪ど減少し，移動度は逆に增加していることが 分かる. Wang ら (5) 放成膜中の窒素がス割合が堌加すると， 作製された試料中の窒素原子割合も増加することを示してい る、このことから窒素がス割合が低いときには，膜が窒素不 足になりやすく，空素空孔または過剰銅原子がドナーの上う な役割をするため高いキャリア密度をとると考えられる。逆 に窒素ガス割合が高い場合には，比較的化学量論組成に近い 試料が作製されたためにドナーサイトが減少し，また結晶粒 のサイズが大さくなったため多数キャりアである電子の散乱 サイトである結晶粒界の影響が減少し移動度が増加したと思 われる。この結晶粒の大きさはXRDプロファイルの


ことで求められた。

次に作製した窒化銅薄膜のバンドギャップエネルギーを算 出した。李ず分光光度計により反射率，透過率を測定し，光 の吸収俰数， $\alpha$ 算出した(7)。算出した光の吸収係数を用い て窒化銅薄膜のバンドギャップェネルギーを求め，その結果 孝Fig. 5 に示す。この図から分かるよらに窒素がス割合が 高い注ど，バンドギャップが広がる傾向にある。屯大成膜時 間が短いはど，つ㐬り膜厚が薄いはどバンドギャップエネル ギーが增加している，成膜時間 $1 \mathrm{~h}$ ，窒素がス割合 $10 \%$ で作 製された試料はバンドギャップが測定できない忹ぞ小さく， このことから看とんぞ金属的な膜(ただしXRD 測定からは

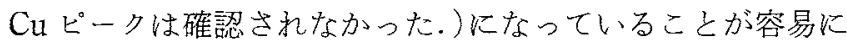
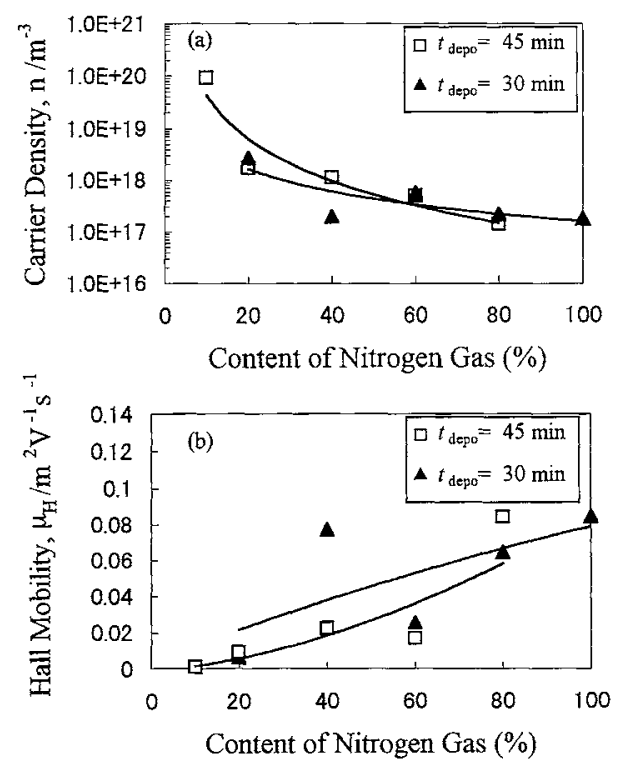

Fig. 4 Dependence of (a) carrier density and (b) Hall mobility on the content of nitrogen gas during the preparation of $\mathrm{Cu}-\mathrm{N}$ films. In these figures, $t_{\text {depo }}$ means the deposition time of $\mathrm{Cu}-\mathrm{N}$ films.
推測される。このようにバンドギャップが測定できない忹ど 小さい試料を除村ば，窒化銅薄膜のバンドギャップエネルギ 一は成膜条件を変化させることで約 $0.5 \mathrm{eV}$ から $1.5 \mathrm{eV}$ をで 変化させることが可能である.非化学量論組成の窒化銅薄膜 は禁制帯内に陷に関係した流ルギ一準位を有するため に，見かけ上バンドギャップエネルギーは小さく見積もられ

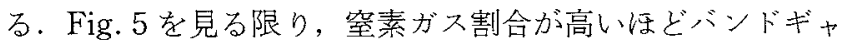
ップェネルギーが大きくなっているので，化学量諭組成に近 い窒化銅薄膜惊窒素ガス割合の時に形成されると考兄られ b.

\section{2. 水素イオン注入の影響}

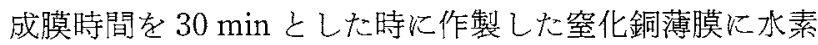
イオン $\left(\mathrm{H}_{2}^{+}\right)$をオン注入装置を用いて注入した。イオン注 入は容易に目的とするイオンを膜中に添加することができる ことから, 半導体薄膜のドーピング技術として盛んに用いら れているが，その反面，試料表面がイオン注入時に損傷し， 二次的な欠陷を導入するといら点を有する ${ }^{(9)}$. そのため今 回の実験に蛙いては入射イオンの加速電在を低く設定し，な るべく試料表面損傷しないよらに注意した.Fig. 6 に水 素イオンを $1 \mathrm{~h}$ 注入した堂化銅薄膜の電気抵抗率を示す. Fig. 6 から明らかなよらに水素イオンを注入すると電気抵抗 率は劇的に減少し，特に低窒素ガス割合で作製した試料では

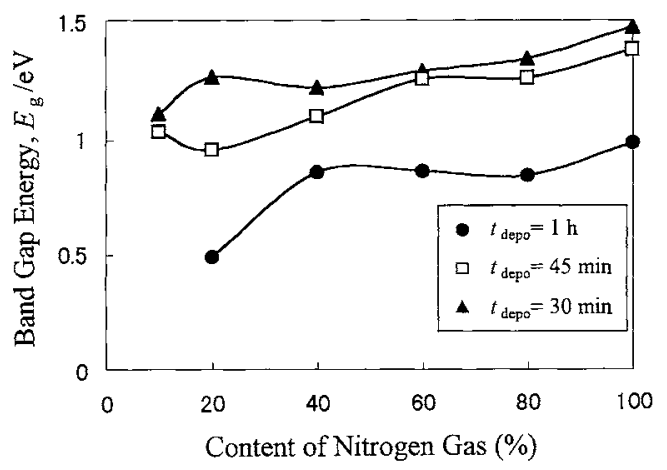

Fig. 5 Dependence of $E_{\text {g }}$ on the content of nitrogen gas during the preparation of $\mathrm{Cu}-\mathrm{N}$ films. In this figure, $t_{\text {depo }}$ means the deposition time of $\mathrm{Cu}-\mathrm{N}$ films.



Fig. 6 Resistivity change between as-deposited $\mathrm{Cu}-\mathrm{N}$ films and $1 \mathrm{~h}$ hydrogen implanted $\mathrm{Cu}-\mathrm{N}$ films. Here, all $\mathrm{Cu}-\mathrm{N}$ films were prepared for $30 \mathrm{~min}$. 

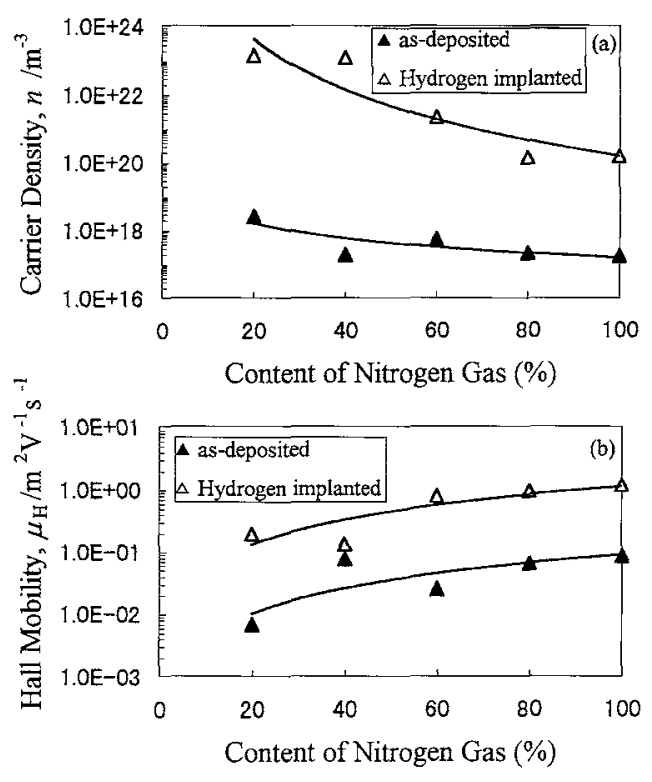

Fig. 7 Hydrogen implantation effect on (a) carrier density and (b) Hall mobility of $\mathrm{Cu}-\mathrm{N}$ films prepared for $30 \mathrm{~min} . \mathrm{H}_{2}^{+}$ ions were implanted for $1 \mathrm{~h}$.



Fig. 8 Band gap energy change between as-deposited $\mathrm{Cu}-\mathrm{N}$ films and $1 \mathrm{~h}$ hydrogen implanted $\mathrm{Cu}-\mathrm{N}$ films. Here, all $\mathrm{Cu}-\mathrm{N}$ films were prepared for $30 \mathrm{~min}$.

$10^{-4} \Omega \mathrm{m}$ にで減少した。この結果は注入乙た水素イオン がドナーの役割を担らサイトを不活性化しない証拠であり, このことは後で述べるキャリア密度の変化にも対応してい る. 水素イオンを注入した試料のホール測定結果をFig. 7 に示す．水素イオン注入後む注入前と同様にすべての試料で ホール係数は負となった. Fig. 7 よ水素イオンを注入する と窒素がス割合 $40 \%$ 以外ではキャリア密度は大幅に増加し，
ホール移動度も増加した.Fig. 6 の電気抵抗率の減少はこの キャリ了密度の増加のためであると思わ机る。ただし辤素が ス割合 $40 \%$ で作製した試料のホール移動度は水素イオンを 注入しても大幅には増加せず，現在その原因を究明中であ る.電気抵抗率のこのような大幅な減少を理解するために,

Fig. 8 に水素イホン注入後の窒化銅薄膜のバンドギャップ エネルギーを示す．水素イオン注入による電気抵抗率の減少 は窒化銅薄膜のバンドギャップが狭まることを予想させる が，Fig. 8 を見ると単純にはそのことが当ては交らないこと が分かる，高窒素がス割合で作製した窒化銅薄膜ではバンド ギャップエネルギーは減少しているが，逆に低窒素ガス割合 で作製した等化銅薄膜では増加しているのである。このこと を理解するには，化学量論組成からのずれを考慮する必要が あるよらに思方れる。

\section{N. 結 訔}

本稿ではこれまであまり研究されなからた公化銅薄膜の特 性評価を主に光学，電気特性を中心に行ってきた。今回の研 究結果から窒化銅薄膜の諸特性が成膜条件に強く影響を受 け，結晶性のよい窒化銅薄膜を作製するためには窒素がス割 合を高くし成膜速度を遅くする必要があることが分かった。 窒化銅はバンドギャップェネルギーが最大で約 $1.5 \mathrm{eV}$ の $\mathrm{n}$ 型半導体であることが明らかとなった。高た本稿では水素イ


は窒化銅薄膜の光学特性や電気特性に明確な変化をるたらし た。特に水素イオン注入後の電気抵抗率は注入前の4 桁か 56 桁活に減少し, こ礼は水素注入を行った結果, 膜中の キャリア密度が劇的に增加したことに関係がある。このよう に水菜イオンを注入することでキャりアの数を大幅に増加で きるよらな材料榁化物薄膜ではあ交り知られていない。こ のような傾向が窒化銅に特有のものなのかどらかはまだ明ら かではないが，新しい機能の誘起を水素イオンが引き起こす 可能性がある.

\section{文献}

(1) S. Nakamura: Jpn. J. Appl. Phys., 30(1991), L1705.

(2) S. Nakamura: Jpn. J. Appl. Phys., 30(1991), L1708.

(3) S. Strite and H. Morkoç: J. Vac. Sci. Technol. B, 10 (1992), 1237.

(4) T. Maruyama and T. Morishita: J. Appl. Phys., 78(1995), 4104.

(5) Dao-yuan Wang, N. Nakamine and Y. Hayashi: J. Vac. Sci. Technol. A, 16(1998), 2084.

(6) S. J. Pearton: Appl. Phys. A, 43(1987), 153.

（7）長友隆男：透明導電性膜の評価，薄膜材料の測定・評価，材 料技術協会, (1991).

（8）米沢貞次郎他：化学物理，才一公社，(1967)，287.

(9) 青太 康: 表面科学, 18(1997), 262. 